\title{
LUÍS GONZAGA GOMES E A MACAU MITOLÓGICA: A AFIRMAÇÃO DE UMA IDENTIDADE SINGULAR
}

\author{
LUÍS GONZAGA GOMES AND THE \\ MYTHOLOGICAL MACAU: THE \\ AFFIRMATION OF A SINGULAR IDENTITY
}

Fernando Ulisses Mendonça Serafim ${ }^{1}$

\begin{abstract}
RESUMO
Luís Gonzaga Gomes (1907-1976) é um dos mais reputados sinólogos em língua portuguesa. Macaense de nascimento, sua contribuição se estende não apenas ao domínio da historiografia daquele território, mas também ao da filologia, cultura popular, língua e até mesmo da música. Foi um intelectual cujo rigor ajudou a estabelecer uma identidade macaense em termos documentais e científicos. Também coligiu algumas lendas e narrativas míticas correntes em Macau em seu tempo. Neste trabalho, pretendemos evidenciar o quanto o mito, representado aqui por tais narrativas, pode ter auxiliado esse trabalho de fixação identitária.
\end{abstract}

PALAVRAS-CHAVE: sinologia; mito; Macau.

\section{ABSTRACT}

Luís Gonzaga Gomes (1907-1976) is one of the most relevant sinologists that write in Portuguese. Born Macanese, he contributed not only on historiographic matters, but also on philology, popular culture, language and music subjects. His rigorous action as a scholar helped Macanese to found their identity through documental and scientific means. He also collected some current legends and mythical narratives at that time. In this paper we intend to reveal how myth, here shown by these narratives, could have aided this effort to develop an identity fixation.

KEYWORDS: sinology; myth; Macau. 


\section{LUÍS GONZAGA GOMES, INTELECTUAL MACAENSE}

É unânime entre os estudiosos da historiografia de Macau a importância dos estudos de Luís Gonzaga Gomes no que tange à catalogação e análise de dados sobre o território. Seria de fato incontornável pretender criar alguma reconstituição da aventura portuguesa em Macau no século $\mathrm{XX}$ sem avaliar o quanto este historiador, professor, jornalista, tradutor, músico e cronista contribuiu para a visualização das mazelas da Macau de seu tempo, bem como para a leitura desse riquíssimo espaço de interação entre as culturas chinesa e portuguesa. Foi aluno de Silva Mendes e Camilo Pessanha no Liceu de Macau, durante a sua juventude. Alguns anos mais tarde, lecionou nessa mesma escola.

Seus escritos sobre Macau, entretanto, ultrapassam a reconstituição histórica na medida em que se ligam a uma espécie de reconhecimento da condição macaense dentro do contexto cultural do Oriente. Ou melhor, de um Oriente em certa medida aportuguesado. O que equivale dizer que, se por um lado, Macau era reconhecida pelos portugueses como um legítimo território seu desde 1557, na verdade a situação política do território foi, durante todo o período da presença governamental portuguesa, extremamente confusa devido à relutância chinesa em considerá-lo de fato um espaço "estrangeiro"2. Ciente desse impasse histórico, "Inho" Gomes, como era conhecido pelos seus alunos do Liceu, procura encontrar, por meio de seus estudos sobre a China, o lugar da cultura macaense, incluindo os chineses, seus costumes e sua vida cotidiana na grande teia de mistificações originárias de um discurso predominantemente eurocêntrico - aportuguesado, leia-se - sobre Macau ou sobre o Oriente ${ }^{3}$ :

Luís Gonzaga Gomes identifica maneiras de viver específicas, bastante particularizadas em relação ao arquivo ocidental de conhecimentos genéricos da cultura e da civilização chinesas estabelecido pela sinologia. [...] Além de entretecer as suas descrições com histórias que circulam entre a população chinesa, o autor busca demonstrar modos próprios de localização da cultura chinesa em Macau. (SIMAS, 2007, p. 146).

A inclusão, numa espécie de simbiose de culturas, entre as matrizes portuguesa e chinesa não é uma prática comum nos textos que se referem a Macau. No mais das vezes, eles são bastante duros a respeito dos costumes do povo chinês. Luis Gonzaga Gomes pertence, portanto, a uma espécie particular de cronistas que se detêm às "chinesices" daqueles que atravessavam o portão fronteiriço (as Portas do Cerco) e se instalam em Macau, observando as ruas macaenses, para depois extrair daí alguma comunicação distante da pura maledicência que marca o discurso colonialista português sobre o Oriente. Chinesices (1952) é um dos livros dedicados a descrever essa Macau por meio de crônicas, descrições toponímicas e narrativas lendárias. Um dos livros entre outros, como Curiosidades da Macau Antiga (1952), que se dedicam a apresentar esse território aos demais portugueses, sobretudo aos da Europa. 
Ocorre, entretanto, um movimento inusitado dentro dessa perspectiva de abertura. Já pelo título do livro, Chinesices (palavra que pode estar associada a um tom pejorativo ${ }^{4}$ ), entrevemos que a própria visada do autor sobre o deslocamento entre dois mundos tão diferentes pode trazer alguns preconceitos à tona. Outros autores, como os próprios Silva Mendes e Camilo Pessanha, os quais fizeram suas vidas em Macau, se dirigiam muito frequentemente ao povo chinês de forma depreciativa ${ }^{5}$. Apesar da adesão a um discurso mais aberto à diversidade cultural, Luís Gomes mantém traços extremamente conservadores em sua atuação como agente cultural, de maneira que para Vanessa Sergio, sua comentadora mais embasada, é possível inscrevê-lo sem receio nas fileiras do salazarismo ${ }^{6}$. Isso porque a atuação profissional de Gomes, sempre ligada ao aparato oficial português, pode também ser levantada como um sinal que revela a sua opção pelo fortalecimento da intervenção portuguesa, jamais obtida de forma decisiva. Os escritos opinativos de Luís Gonzaga Gomes, expostos por Vanessa Sergio, referendam a voz conservadora da "metrópole" e a busca pelo poder local. Há, como veremos, alguma irregularidade discursiva passível de observação nesse trajeto, mas os fatos elencados pela pesquisadora, evidentemente, não devem ser elididos.

\section{O PRINCÍPIO DO MITO E A MACAU "ANTIGA"}

A interlocução que se inaugura pelo contato entre a narrativa mítica nos escritos de Gonzaga reforça uma espécie de capital identitário que remete não apenas à experiência do português em Macau, mas também à (muito mais abundante) influência chinesa na cidade. Ou seja, a cidade "entra" na narrativa como personagem e também como paisagem. Macau entra, mais do que como um dado sociológico, como uma espécie de organismo vivo, dentro do qual pulsam dramas, tensões e histórias pitorescas. A prerrogativa de contar Macau, desta vez, é de um macaense, o que enseja um variado rol de temas a abordar, como se descrevendo quadro a quadro o cotidiano macaense, o autor pudesse não apenas comunicar a particularidade histórica da cidade, mas também incluí-la dentro de um mapa de afetos. É necessário que lembremos, contudo, que o destinatário da "mensagem" ainda é o leitor médio português com algum interesse pela China. Por isso, a multiplicidade de recortes temáticos pretende emular um excesso de informação que dê conta de superar o esperado desconhecimento sobre o assunto:

Em Chinesices (1951), o autor enuncia e descreve elementos da esfera sociocultural chinesa, como as organizações das casas de penhor, o sistema de recrutamento dos funcionários por meio de exames públicos, a história da indústria da seda, incluindo sua lendária origem, a história do uso de ervas chinesas para tratamentos de doenças, as formas de luta chinesa, o sistema da geomancia, os jornais chineses, o ritual de casamento, os jogos e as atividades profissionais dos vendilhões ambulantes e das penteadeiras. (SIMAS, 2007, p. 146) 
Não é apenas de instantâneos, contudo, que se compõem as figuras $^{7}$ que descrevem o universo chinês/macaense. O funcionamento tradicional da sociedade chinesa, ou seja, sua estrutura mais profunda, encontra uma alentada expressão nos escritos de Luís Gonzaga Gomes. Isso quer dizer que, ao reconhecer a tradição como pedra fundamental do cotidiano macaense, torna-se necessário também que o texto se valha, mesmo em grau superficial, do reavivamento de costumes chineses. É como se o autor, por meio da descrição tópica dos lugares comuns chineses, nos fizesse chegar a um estrato mais próximo da ancestralidade de sua cultura. De maneira que se torna impossível encontrar a Macau "verdadeira" e comezinha sem retomar os mais recuados temas da sinologia. A propósito disso, e já prevendo a implicação de várias camadas de conhecimento para delinear a vida macaense, os livros ligados ao estrato da narrativa em Luís Gonzaga Gomes precisam contar não apenas com a força do assombro que parte da visão exótica, mas também com uma série de expedientes muito mais ligados à tradição moral e religiosa:

Cette lecture des contes et des légendes, laissés par lauteur macanais, s'appuie sur un corpus de textes extraits des recueils suivants : Contos chineses (1950); Lendas chinesas de Macau (1951); Curiosidades de Macau Antiga (1952) et Chinesices (1952). Un regroupement des textes, en quatre groupes thématiques, a été entrepris : valeurs morales chinoises; superstitions et croyances chinoises; rencontre avec la civilisation chinoise ; puis, divinités protectrices du panthéon chinois. Cette répartition thématique des contes et des légendes n'enferme pas, de manière définitive, chaque récit dans une catégorie. Un même récit peut ainsi réunir différents éléments ou motifs qui se croisent, caractéristiques de thèmes thématiquement distincts ${ }^{8}$. (SERGIO, 2012, p. 302).

Das quatro dimensões descritas por Vanessa Sergio, três se ligam à espiritualidade: os "valores morais chineses", as "superstições e crenças" e as "divindades protetoras do panteão chinês". Isso se considerarmos que o "encontro com a civilização chinesa" não vá desembocar numa das outras dimensões elencadas, o que a própria autora sugere ser muito difícil. "Encontrar a civilização chinesa", para Luís Gomes, é transitar pelas praças para ouvir as vozes que gritam, e em meio ao alarido dessas vozes, encontrar o sentido mais profundo desse contar. De modo que, ao descrever o antigo hábito chinês de contar, o próprio autor reflete o seu apreço por essa forma, chamando de "contos", "fatos" e "lendas" os aspectos sociais que descreve em suas andanças pelas ruas de Macau. O seu olhar é, como afirma Vanessa Sergio, de um "passeur", um passante que sem compromisso, descreve a um interlocutor o que vê. $\mathrm{E}$, ao contar o que vê, não se detém apenas naquilo que salta aos olhos, mas no âmbito do que aquilo representa como lugar de cultura: 
No Verão, é frequente ver em Macau, principalmente durante o dia e em sítios abrigados do Sol, diferentes grupos constituídos por chineses de variada idade, que se assentam ou se acocoram no chão, para ouvirem com concentrada atenção a arenga de diversos indivíduos, sordidamente recobertos de andrajos, vislumbre do que outrora foram ricas véstias de seda. [...] Tais assembleias [...] não são mais que reuniões de pacatos burgueses, que se juntam em volta de vários narradores profissionais para ouvirem as histórias que eles contam. Na China, há muita gente que prefere frequentar um desses círculos, não só para se poupar ao trabalho de ler um romance ou uma novela, mas porque o povo se delicia com os comentários que os narradores fazem às diversas peripécias por que passam os seus heróis, prazer esse que não lhe pode ser proporcionado pelos livros, cuja leitura é demasiado árida, em virtude da concisão e laconismo com que são expressas as ideias, na intrincada escrita chinesa. (GOMES, 1994b, p. 95)

O passeio aparentemente despretensioso que revela o costume burguês de ouvir histórias na verdade revela mais do que isso: revela a própria desídia (ou talvez a dificuldade) de um certo estrato social chinês em decifrar os seus mitos literários ${ }^{10}$; revela também o laconismo de um idioma abundantemente alusivo, no que o autor deixa implícita a sua concordância com estudiosos como Ernest Fenollosa, em seus estudos sobre a escrita ideogramática ${ }^{11}$. Porém, mais do que aquilo que se conta, o que está aqui em evidência é o próprio alcance desse contar, como também a maneira como esse contar é performado: uma "arenga" levada a cabo por "indivíduos sordidamente recobertos por andrajos”. Os enunciadores desse mundo mítico a que pertencem as narrativas antigas são os proscritos, aqueles que não passam de "vislumbres" de um tempo antigo. É uma forma bastante particular, sem dúvida, de representar um passado imaterial, e não podemos deixar de perceber o desprezo com que Gomes revela os portadores dos segredos míticos de Macau. O passeio pelo mundo do mito pode ser também interpretado como uma prova histórica de caducidade da cultura e sociedade chinesas, mesmo apesar dessa tentativa de mediação cultural. Isso diz muito a respeito sobre o modo como Gomes e outros cronistas ocidentais (e/ou colonialistas), depositaram no âmbito da falta de civilidade, de modos ou sob uma chave decadentista a história desse "outro":

Formalmente, o orientalista vê-se como aquele que realiza a união entre o Oriente e o Ocidente, mediante, principalmente, uma reafirmação da supremacia tecnológica, política e cultural do Oeste. A história, nessa união, é radicalmente atenuada, se não banida. Vista como uma corrente de desenvolvimento, como uma linha narrativa ou como uma força dinâmica que se desenrola sistemática e materialmente no tempo e no espaço, a história humana - do Leste ou do Oeste - é subordinada a uma concepção essencialista e idealista de Ocidente e de Oriente. Sentindo estar na linha divisória entre 
o Leste e o Oeste, o orientalista não se limita a falar em vastas generalidades; ele procura também converter cada aspecto da vida oriental ou ocidental em um sinal sem mediações de uma ou outra metade geográfica. (SAID, 1996, p. 251)

Os episódios da vida chinesa, dessa maneira, encontram expressão na medida em que se afirmam como uma realidade alheia ao Ocidente. É por isso que certos eventos particularmente marcantes na cultura chinesa agem como marcadores da diferença (ou da ponte, a depender do texto) entre um lado e outro do globo. A ubiquidade dessas manifestações determina uma narrativa calcada na diferença, o que representa a base desse "Oriente como invenção do Ocidente” ao qual o título do Orientalismo alude.

Talvez seja preciso arrazoar, entretanto, que essas diferenças também ajudam a definir traços profundos das comunidades. Seus mitos e referências são, afinal, testemunhos culturais que, pelo bem ou pelo mal, partem de um macaense. A voz que enuncia essas pistas é o tom determinante do modo como essa notícia de terra estrangeira chegará. E muito embora Luís Gomes se fie ao discurso colonial, é também a ele que se devem descrições muito vívidas de costumes chineses muito caros à sua origem macaense. É aí que emerge a força desse contar atemporal, e aí está um impasse fundamental da obra de Luís Gomes: a cisão entre o viver - no que ele é experiência e conhecimento - e o contar, ou a contaminação discursiva (orientalista) desse contar.

Para ilustrar a força do mito como reforço de uma identidade macaense, devemos recorrer, infelizmente de maneira muito sumária, a alguns textos exemplares de Gomes que remetem ao cotidiano cultural macaense. Há, no livro Macau: Factos e lendas, uma detida descrição dos eventos que precedem a virada do Ano Novo lunar. O modo como as cidades são arrumadas, os enfeites necessários utilizados exclusivamente para as cerimônias (as quais, a propósito, são minuciosamente descritas), as diversas oferendas feitas pela população... Inúmeros são os aspectos da festa abordados por Luís Gonzaga Gomes. Vamos nos ater a um em especial, aliás muito pitoresco, que consideramos bastante ilustrativo em termos daquilo que representa como expressão de sacralidade:

Além dos dísticos auspiciosos, os chineses costumam também colar nas suas portas, nessa ocasião, as efígies dos Mun Sân (deuses das Portas), que foram, em época desconhecida, dois irmãos que viveram debaixo dum pessegueiro tão grande, que cinco mil homens de braços estendidos não conseguiam abraçar o seu adansonesco tronco. [...] Há, porém, quem conte que os deuses das Portas foram, em vida, dois dedicados generais do Imperador T'Ai Tchông (627-650 a.D.). Este, após o seu fiasco, na expedição que empreendeu contra a Coreia passou a ser perseguido por súcubos. Os dois generais, condoídos com o desespero em que vivia o ilustre amo, resolveram postar-se, cada um, nas portas de 
sua alcova, prontos a lutar com os demónios, que pretendessem franqueá-las para irem perturbar o seu imperial senhor. Estes, que conheciam a indomável bravura daqueles dois guerreiros, não se atreviam a acometê-los. [...] O imperador, vendo, porém, que não era justo que os seus fiéis generais se sacrificassem perdendo as noites em vigília, só para o seu bem-estar, lembrou-se de mandar pintar nas portas as suas efígies. [...] Ante a indiscutível eficácia de tão simples processo de afastar os espíritos malfazejos, o povo passou também a colar as imagens desses guerreiros nas portas de suas residências. (GOMES, 1994b, p. 126)

O enfeite das portas que recepciona a chegada dos deuses e espanta os demônios na ocasião do Ano Novo merece a descrição detida de Luís Gonzaga Gomes não apenas por representar o cuidado com os preparativos. Ele faz o leitor ocidental, seu interlocutor privilegiado, embrenhar-se na espiritualidade popular chinesa em seu tempo transfigurado: terror, nobreza e devoção encontram-se no trânsito dos espíritos. De maneira análoga, não é raro também encontrar esse tempo recuado como repositório de uma suposta crueldade oriental - e esse é, de fato, uma tópica intensamente explorada pelo discurso orientalista português ${ }^{12}$.

No caso da descrição do Ano Novo, a repercussão do tempo ancestral é sentida novamente a cada festividade; renova-se o mito e, assim, novamente a história é contada. Fica, sobretudo, o valor moral da obediência, o ponto a que Luís Gonzaga Gomes provavelmente pretende chegar por meio de uma narrativa exemplar. Fica além de tudo a grandeza da ameaça dos maus espíritos, que podem ser sossegados apenas dentro de um ritual absolutamente incorporado à vida, indefinidamente renovado. A crendice popular parece justificada, como se pela precaução e por algum respeito ritual o autor reafirmasse o ditado espanhol: "no creo en brujas, pero que las hay, las hay”. As festividades, a propósito, tomam inúmeras páginas dos contos de Luís Gonzaga Gomes. São páginas em que as descrições se destacam pelo brilho, pelo viço de um tempo passado, o qual pode apenas ser revivido por uma memória - que não é a do próprio autor, uma vez que ele ainda não havia nascido:

Nessa noite, a Praia Grande, desde o largo do Chunambeiro (hoje Praça Lobo d’Ávila) até ao quartel do batalhão, mostrou-se garridamente engalanada, exibindo uma fila contínua de balões multiformes e multicores. As fachadas das moradias, ao longo dessa avenida, apresentavam-se primorosamente iluminadas, diligenciando os seus proprietários, por se superarem uns aos outros em riqueza de ornamentação, originalidade e bom gosto, sendo de destacar o palácio do barão de Cercal, que tinha, no centro da grande varanda, uma luz eléctrica - autêntica novidade para a época - levando as espias até ao topo do mastro do consulado - era ele cônsul de Itália - balões de variadas cores. (GOMES, 1994b, p. 32) 
Nesse texto, "A vida em Macau há cerca de cem anos", Luís Gomes descreve a cidade em 1872, pintando-a com cores do mais alto esplendor, fiando-se ao relato daqueles que o precederam. $O$ fausto com que ele descreve a Macau antiga em nada se assemelha à decadência da turba dos narradores profissionais. $\mathrm{O}$ mundo de beleza a que ele se refere não raro está cercado de um requinte institucional, proporcionado por embaixadores e representantes governamentais europeus. E não apenas nesse, como também em outros relatos, os detalhes de tais festividades são revelados à exaustão, como se reconstituindo esse esplendor, o autor revisitasse uma espécie de paraíso perdido. Frequentes são também as histórias de amor entremeadas pela ação da morte, dos espíritos e da natureza, como convém aos mitos mais populares:

Assim, no dia seguinte, quando o Sol se ocultou atrás da colina da Lapa, os dois amantes, tendo findado o seu trabalho diário na várzea, dirigiram-se para trás da capela da Kun Iâm e, depois de se abraçarem e chorarem muito, enforcaram-se, corajosamente, cada um, nos ramos de duas árvores que cresciam isoladas naquele local.

Os espíritos dos dois suicidas nunca mais se aquietaram porém, e desde então, todas as noites, viam-se dois vultos a passear de braço dado, por entre as várzeas.

Depois da meia-noite, os moradores das cabanas desse povoado de Mong-Há não conseguiam pregar olho até ao nascer do Sol, tão aflitivos eram os lamentos soltados por aquelas duas almas penadas. E, fenómeno que causou tão grande espanto, as duas árvores, onde os dois desgraçados amantes se suicidaram, passaram, daí em diante, a desenvolver-se com extraordinária pujança, mas com os seus troncos abraçados um ao outro, como dois seres envolvidos num forte amplexo e com o estranho aspecto com que ficou até hoje. (GOMES, 1994, p. 71)

O excerto descreve como se formou uma frondosa e bela árvore, admirada pela sua força, a qual parece significar a própria analogia à força do amor entre os dois jovens, os quais mantinham um amor impossível em razão de suas origens sociais diferentes. O mito do amor é tomado como uma árvore, como o enraizamento de um sentimento que se tornou de certa forma histórico e que avança oralmente pelas gerações. Mais do que irmanar esse amor à coleção imensa de amores ao redor do mundo, essa narrativa serve para vincar o fato ou a crença de que "este amor nasceu aqui", sendo, portanto, a razão de existência daquele local como patrimônio compartilhado. É um mito corpóreo, visitável. É o espaço em que o corpo da linguagem se funde à presença: signo e narrativa abandonam sua morada suspensa e encarnam a ubiquidade daquele povo-testemunha, daquele relato como verdade e da natureza como poder: 
De mais a mais, para os poetas, o mundo físico foi geralmente não só o mundo cíclico, mas a 'terra do meio', situada entre um mundo superior e outro inferior. Esses dois mundos refletem em sua forma os céus e os infernos das religiões contemporâneas ao poeta e são normalmente pensados como moradias de existência imutável, não como cíclicos. O mundo superior é alcançado como algum tipo de ascensão e é um mundo de deuses e almas felizes. As imagens mais frequentes de ascensão são a montanha, a torre, a escada em caracol ou uma árvore de dimensões cosmológicas. (FRYE, 1999, p. 69)

Porém, nem todo texto de Luís Gomes aceita interpretações desse gênero. Suas crônicas são frequentemente dúbias em relação à abordagem mítica: desacreditar ou reforçar a mediação do mito sobre os seres é parte da dialética de que ele se vale para evocar (num sentido quase ancestral) as forças ocultas que movem os homens. O gregarismo que parte do texto contado em qualquer esquina, o fascínio de/por uma fábula bem construída, e mesmo o mistério da autoria dessas lendas são, inegavelmente, marcadores da convivência de um povo com seus pares, e também com sua história. O contato com o mito reata a liberdade de "criar recriando", uma vez que os contadores das ruas não inventam histórias, apenas as reproduzem dentro de determinados modelos ${ }^{13}$, os quais são inscritos num modelo de elocução que tem como força e base a certeza de sua tradição: "lécrivain chinois n'est pas, par opposition à l'écrivain occidental, um 'créateur' mais um 'glossateur' ou 'commentateur"' ("o escritor chinês não é, em oposição ao escritor ocidental, um 'criador', mas um 'glosador' ou 'comentador"') (SERGIO, 2012, p. 303, tradução nossa). A habilidade do comentador chinês está, portanto, na arte de refundar indefinidamente o mito, explorá-lo em sua ancestralidade até que se chegue a um tempo próprio ${ }^{14}$. De maneira análoga, ao emprestar a seus contos algum grau de atemporalidade, Luís Gonzaga Gomes está retomando a uma Macau pré-portuguesa, a centros de poder e conhecimento ignorados pelo Ocidente ${ }^{15}$. Nesse "padrão de história abstrato" (FRYE, 1999, p. 38), portanto, está incubada o que é a Macau desconhecida, que coincide com uma China igualmente "desconhecida".

O leitor ocidental acede, assim, a uma espécie de Finis Asiae16, um lugar proibido que corresponde à manifestação narrativa de uma cidade proibida para o senso comum ocidental. Nessa cidade, em que pese a arbitrariedade dos acontecimentos, é uma história antiga que recebe uma aura de sacralidade, ou ao menos de integridade. O que é na verdade uma situação paradoxal, que desafia a natureza da presentificação da história, a exigência de veracidade que esperamos desde quando Aristóteles formulou os conceitos de mimese e verossimilhança (muito embora, em alguma instância, ele também estivesse se reportando ao mito). A verdade revelada de uma cidade como Macau não precisa, afinal de um autor: 
O que é certo é que Luís Gonzaga Gomes não identificava as suas fontes, o que torna quase impossível avaliar até que ponto esses escritos provinham de textos chineses, ou de tradições orais que conheceu, ou até de sua própria imaginação. (BATALHA apud SERGIO, 2012, p. 305)

O fato de termos aí exposto um mito implausível e a suspeita carência de fontes poderia, de alguma forma, comprometer a verdade e mesmo a crítica que se faz aos costumes da cidade de Macau. As histórias a que ele se refere são, provavelmente, extraídas de contos muito antigos, como vimos, e se, por um lado, servem ao propósito de vincar uma leitura sobre Macau, parecem, por outro, eventualmente inviabilizar uma leitura racional de seus costumes. Isso ocorre porque os mitos são, para Luis Gonzaga Gomes, uma espécie de sintoma de uma civilização atrasada, presa a conceitos e raciocínios supersticiosos ${ }^{17}$. As fontes de Luís Gomes são em geral apócrifas e certamente esse fato reforça sua condição de incerteza e precariedade. Entretanto, o próprio caráter difuso desse discurso ajuda a referendar a China como a influência definitiva da região. Isso revela aos portugueses a precariedade de sua ocupação no território: os textos que regem a vida em Macau são chineses, assim como os mitos, as origens das esperanças e dos temores. A linguagem, nesse sentido, revela uma instância de poder. As histórias que correm em Macau, supersticiosas ou não, provêm de uma tradição mitológica oriental, e desobedecem em tudo ao racionalismo que o próprio Gomes atribui com frequência ao Ocidente. Se, portanto, os deuses chineses aparecem como protagonistas em suas narrativas, o próprio gesto de pensá-los como a espinha dorsal de uma sociedade enceta um olhar antropológico sobre a cultura chinesa, e é esse gesto empreendido por Luís Gomes que se diferencia da imensa maioria das visadas portuguesas sobre a China. Ela não está inferiorizada ou igualada frente a Portugal: está num patamar superior, na medida em que pode ser percebida tanto epidermicamente quanto de modo mais arraigado. Contudo, é dessa mesma superioridade que se origina a crítica à China, num discurso nitidamente filiado ao orientalismo europeu. A inscrição dessa Macau chinesa no discurso, se por um lado reforça o laço histórico com o Oriente, por outro, refunda o projeto colonialista ao não abandonar os lugares-comuns do ponto de vista europeu.

É como se o gesto de Gomes se opusesse ao discurso: uma capitulação que evidencia a debilidade do domínio português em Macau rivaliza com a continuidade da prática colonial, caracterizada pela regularidade de traços orientalistas em sua fala. Esse fenômeno adquire um vulto muito maior se considerarmos que Luís Gonzaga Gomes era um macaense dono de um poderoso instrumental retórico e científico ocidental, muito embora vivesse inteiramente, como o próprio território de Macau, cercado de China por todos os lados. Não se trata, evidentemente, de um caso único na história colonial portuguesa, mas a singularidade de sua contribuição para a fixação histórica da cultura macaense pode sem dúvida insuflar o debate. 


\section{REFERÊNCIAS BIBLIOGRÁFICAS}

FRYE, Northrop. Fábulas de identidade: Estudos de mitologia poética. Tradução de Sandra Vasconcellos. São Paulo: Nova Alexandria, 1999.

ELIADE, Mircea. Mito e realidade. Tradução de Pola Civelli. São Paulo: Perspectiva, 2011.

GOMES, Luís Gonzaga. Chinesices. Macau: Instituto Cultural de Macau, 1994a.

. Macau: factos e lendas. Macau: Instituto Cultural de Ma-

cau, 1994b.

Curiosidades de Macau antiga. Macau: Instituto Cultural

de Macau, 1996.

LABORINHO, Ana Paula; SEIXO, Maria Alzira; MEIRA, Maria José (orgs.) A vertigem do Oriente: Modalidades discursivas no encontro de culturas. Lisboa/Macau: Cosmos/Instituto Português do Oriente, 1999.

PESSANHA, Camilo. Contos, crónicas, cartas escolhidas. Org. António Quadros. Lisboa: Europa-América, 1988.

PIRES, Daniel (org.). Homenagem a Camilo Pessanha. Macau: Instituto Cultural de Macau / Instituto Português do Oriente, 1990.

QUEIRÓS, Eça de. Chineses e japoneses. Lisboa: Cotovia/Fundação Oriente, 1997.

RUBIM, Gustavo. Pessanha - Exota: catálogo. Lisboa, 2008: Catálogo da Exposição realizada pela Fundação Calouste Gulbenkian: Weltliteratur: Madrid, Paris, Berlim, São Petersburgo, o Mundo!

SAID, Edward. Orientalismo: O Oriente como invenção do Ocidente. Tradução de Tomás Rosa Bueno. São Paulo: Companhia das Letras, 1996.

SERGIO, Vanessa. Macao: vie culturelle et littéraire d'expression portugaise au milieu du XXe siècle - Luís Gonzaga Gomes, "Fils de la terre". 2012. 581 p. Tese (Doctorat en Langues, Littératures et Civilisations Romanes: Portugais). Université Paris Ouest Nanterre La Défense, Paris, 2012.

SIMAS, Monica. Margens do destino: Macau e a literatura em língua portuguesa. São Caetano do Sul: Yendis, 2007.

Recebido para publicação em 31/05/2018

Aprovado em 20/08/2018 


\section{NOTAS}

1 Doutorando em Teoria e História Literária pela Universidade Estadual de Campinas (Unicamp), Mestre em Literatura Portuguesa pela Universidade de São Paulo (USP).

$2 \mathrm{O}$ tema é extenso e muito controverso. Mônica Simas descreve o início da presença portuguesa em Macau, que de certa forma resume o modo como os chineses encaravam sua situação política em relação aos portugueses durante vários séculos: "De maneira muito geral e breve, pode-se dizer, sobre a questão dos motivos da ocupação portuguesa, que nunca foram encontradas as chapas sínicas que comprovariam a cedência de Macau por conta do auxílio prestado no combate aos piratas. Não há nenhum documento que comprove definitivamente essa versão da ocupação, presente no imaginário dos habitantes de Macau, tradição de vasta literatura. Também aparecem como razões do estabelecimento dos portugueses em Macau, além da versão relacionada à expulsão dos piratas, a conversão de um posto mercantil temporário em estabelecimento permanente, por meio do suborno de mandarins, ou o desembarque para secar mercadorias, com a subsequente construção de casas. Já entre as fontes chinesas, comumente aparece (mas não de forma exclusiva) a defesa da ideia de uma ocupação progressiva graças aos interesses dos poderes chineses regionais. Nessas versões, os portugueses, também considerados piratas, têm importância na região chinesa do Sudeste Asiático por causa de sua capacidade de navegar, combater e comerciar, e Macau, uma pequena península ligada ao continente por um estreito istmo, servia bem aos interesses chineses locais de administrar e controlar a presença estrangeira." (2007, p. 11-12)

3 Eça de Queirós comenta, sem deixar de lado a sua verve irônica, o discurso corrente sobre os chineses. Vale lembrar que, uma vez provinda da cantilena colonial, tal fala se dissemina não apenas no século XIX, mas também durante o século XX, por meio do salazarismo: "Para o europeu, o chinês é ainda um ratão amarelo, de olhos oblíquos, de comprido rabicho, com unhas de três polegadas, muito antiquado, muito pueril, cheio de manias caturras, exalando um aroma de sândalo e de ópio, que come vertiginosamente montanhas de arroz com dois pauzinhos e passa a vida por entre lanternas de papel, fazendo vénias. [...] Como por vezes as suas populaças trucidam os nossos missionários, a estes traços de carácter (tão exatamente deduzidos) juntamos também o da ferocidade. Porque os chineses não querem ter caminhos de ferro, nem fios de telégrafo, nem candeeiros de gás, que constituem para nós as expressões sumas da civilização, concluímos rasgadamente que são bárbaros." (QUEIRÓS, 1997, p. 33-34)

4 "Esse termo genérico é frequentemente empregado pela comunidade portuguesa de Macau - às vezes com superioridade ou desprezo - para designar tudo o que se liga à cultura chinesa e aos chineses." (SERGIO, 2012, p. 310, tradução nossa)

50 prefácio ao Esboço crítico sobre a civilização chinesa, livro do médico Morais Palha, é o mais cabal exemplo desse discurso na obra de Camilo Pessanha. Nele, o poeta dedica toda uma página a insultar os chineses seus contemporâneos, sem qualquer tipo de ressalva. Também não é difícil encontrar nas crônicas de Silva Mendes críticas severas aos chineses, muito embora sua crítica mais direta remeta aos próprios portugueses, mormente por motivos políticos.

6 "Luís Gonzaga Gomes encarna a mentalidade colonial da época e reivindicará até o fim uma identidade e uma cultura portuguesas, profundamente ligadas aos valores veiculados pelo regime salazarista. Como o ilustra a visão (muito resumida) de Johny Si Tou, a identidade macaense se inscreve (e se constrói) no lugar com Portugal e sua cultura. 'Filho da terra', Luís Gomes cresceu com a ideia de 'nação' e de 'unidade nacional', dois conceitos ideológicos próprios à história da expansão colonial de Portugal. Assim, a metrópole e suas diferentes províncias de ultramar (ou antigas colônias) formam um todo (considerado) homogêneo e harmonioso, representando essa famosa 'unidade nacional', profundamente enraizada na memória coletiva de cada território português". (SERGIO, 2012, p. 37, tradução nossa) 
7 “Além dos aspectos socioculturais, tratados pela evocação de profissões antigas ou de lazeres próprios à comunidade chinesa - como a luta de grilos -, Luís Gonzaga Gomes explora também, com minúcia, a topografia e a toponímia do território. Esses contos e lendas permitem ao autor atravessar diferentes épocas como o tempo místico da China antiga, mas também a China Imperial, com suas dinastias, ou ainda, mais raramente, a época mais contemporânea da primeira metade do século XX”. (SERGIO, 2012, p. 308, tradução nossa)

8 "Esta leitura de contos e de lendas, deixadas pelo autor macaense, se apoia num corpus de textos retirados das seguintes coletâneas: Contos chineses (1950); Lendas chinesas de Macau (1951); Curiosidades de Macau Antiga (1952) e Chinesices (1952). Um agrupamento dos textos, em quatro grupos temáticos, foi estabelecido: valores morais chineses; superstições e crenças chinesas; encontro com a civilização chinesa; por último, divindades protetoras do panteão chinês. Essa repartição temática dos contos e das lendas não informa, de maneira definitiva, cada narrativa em uma categoria. Uma mesma narrativa pode assim reunir diferentes elementos ou motivos que se cruzam, característicos de assuntos tematicamente distintos". (SERGIO, 2012, p. 302, tradução nossa)

9"Os contadores profissionais de Macau, que frequentemente se acompanham de música, se faziam nos salões de chá, ou na rua, até os anos 1960. Parecia legítimo perguntar se Luís Gonzaga Gomes, que escreveu sobre essas figuras sociais, não seria inspirado pelas lendas ouvidas em praça pública. Esses contadores tinham como tarefa divertir seu auditório e instruí-lo. Essa função didática endossada pelo contorno, que juntava os valores morais próprios ao povo chinês, é retomada de maneira explícita por Luís Gonzaga Gomes, que assume assim plenamente seu papel de 'Passante"'. (SERGIO, 2012, p. 306, tradução nossa)

10 A dificuldade em decifrar a escrita literária chinesa pode ser aferida, por exemplo, pela dificuldade relatada por Camilo Pessanha para elucidá-la: "Uma das mais flagrantes características da poesia chinesa, e sem dúvida, o mais difícil obstáculo à sua cabal exegese pelos ocidentais está nesse gosto exagerado pela alusão histórica ou literária, que numerosas passagens, e, até poemas inteiros, tenham duplo sentido, - um superficial e outro profundo. Claro que, em tais condições, o tradutor que não esteja aparelhado com uma vasta cultura sinológica, navega em permanente risco de soçobrar de encontro a invisíveis, traiçoeiros cachopos. Acresce [...] a própria imprecisão da linguagem, que no chinês literário é qualidade fundamental, chegando as palavras a não ter significado próprio - tão divergentes e, até, opostas são as acepções de cada uma, e - sendo, por seu lado, a frase [...] susceptível, por falta de leis sintáxicas que presidam à sua estrutura, das interpretações mais contraditórias.” (PESSANHA, 1988, p. 157)

11 Ernest Francisco Fenollosa (1853-1908), americano radicado no Japão, escreveu um importante texto, The Chinese Written Character as a Medium for Poetry, que foi editado e divulgado por Ezra Pound em 1919. Trata-se de uma obra de "sinologia poética", como diz Gustavo Rubim (2008), sobre a estética chinesa (mais especialmente da capacidade alusiva de seus caracteres). Para Edward Said, contudo, tanto os estudos de Fenollosa quanto o interesse de Pound não vão muito além do que ele apresenta como um corpus de "abstrações de segunda mão" sobre o Oriente (SAID, 1996, p. 258).

12 Como exemplo, citamos uma fala de Camilo Pessanha sobre as crueldades de um tal juiz: "Aqui, de Macau, e pela mesma ocasião em que o Lam-Kua-Si foi extraditado, foi-o também um mandarim, o célebre Pui-Keng-Fôc, juiz criminal de Nam-Hoi, cuja perversidade não era menos requintada do que a do famigerado bandoleiro. Esse mandarim, parecendo-lhe pouco variados os suplícios atrozes em uso no seu tempo, dedicou-se com uma paixão de arqueólogo ao estudo da história judiciária chinesa para ressuscitar e por em moda obsoletas espécies de morte aflitiva, mais ou menos acrobaticamente macabras, esquecidas desde havia séculos. Entre esses suplícios restaurados estava a sensacional morte de gaiola, em que o paciente era suspenso pelo gasnete, mas de modo a poder apoiar no chão os dedos dos pés, e deixado nessa divertida posição, de equilíbrio instável, até morrer de esgotamento." (PESSANHA, 1988, p. 125). 
13 "Sobre a origem e fonte - ou fontes - de inspiração desses contos, escritos por Luís Gonzaga Gomes, muitas pistas trazem elementos de resposta. Algumas narrativas longas e repetitivas, que deixavam transparecer a dimensão oral, sugerem que o autor poderia ter transcrito histórias contadas pelos contadores chineses de Macau." (SERGIO, 2012, p. 302, tradução nossa)

14 “O indivíduo evoca a presença dos personagens dos mitos e torna-se contemporâneo deles. Isso implica igualmente que ele deixa de viver no tempo cronológico, passando a viver no Tempo primordial, no Tempo em que o evento teve lugar pela primeira vez. É por isso que se pode falar no "tempo forte" do mito: é o Tempo prodigioso, "sagrado", em que algo de novo, forte e significativo se manifestou plenamente." (ELIADE, 2011, p. 22, grifos do autor)

15 A narrativa mitológica funciona dentro do desconhecimento, o que a situa num espaço de arbitrariedade: "Por mito [...] refiro-me primariamente a um certo tipo de história. É uma história na qual alguns dos personagens são deuses ou outros seres mais poderosos que a humanidade. Raramente ela está situada na história: sua ação acontece num mundo acima ou anterior ao tempo comum, in illo tempore, na expressão de Mircea Eliade. Por isso, assim como o conto popular, ela é um padrão de história abstrato. Os personagens podem fazer o que querem, o que significa o que o narrador quer: não há necessidade de ser plausível ou lógico em motivação. As coisas que acontecem no mito são coisas que acontecem apenas em histórias; elas estão em um mundo literário autossuficiente". (FRYE, 1999 , p. 38)

16 Remissão ao Finis Africae, cômodo em que se guardava o segredo do convento - o texto de Aristóteles sobre o riso - no livro O nome da rosa, de Umberto Eco.

17 "Pelo viés dessas narrativas, o autor descreve a sociedade chinesa pelos seus costumes, seus modos e suas crenças, que ele denuncia por vezes com um certo desprezo, típico da mentalidade colonial da época." (SERGIO, 2012, p. 309, tradução nossa). 